\title{
MENINGKATKAN HASIL BELAJAR SISWA MENGGUNAKAN MODEL ROLE PLAYING PADA MATERI SENI RUPA DUA DIMENSI DI SMAN 1 LABUHAN DELI
}

\author{
Nurambia \\ Sekolah Menengah Atas Negeri 1 Labuhan Deli \\ Jl. Serbaguna Ujung Pasar IV, Desa Helvetia, Kec. Labuhan Deli, Kab. Deli Serdang, Kode Pos 20373 \\ Sumatera Utara. Indonesia \\ Email: nur.ambia63@gmail.com
}

\begin{abstract}
Abstrak
Pendidikan Seni Budaya berfungsi mengembangkan kepekaan rasa, kreativitas,dan cita rasa estetis siswa dalam berkesenian, mengembangkan etika, kesadaran sosial dan kesadaran kultural siswa dalam kehidupan bermasyarakat, serta rasa cinta terhadap kebudayaan Indonesia. Salah satu materi Seni Budaya yang dpelajari untuk tingkat Sekolah Menengah Atas adalah tentang seni rupa dua dimensi. Namun siswa di kelas X IIS 1 SMA Negeri 1 Labuhan Deli mengalami kesulitan sehingga hasil belajar seni rupa dua dimensi menjadi rendah. Oleh karena itu dilakukan penelitian ini yang bertujuan untuk meningkatkan hasil belajar siswa menggunakan model Role Playing. Penelitian ini merupakan penelitian tindakan kelas (PTK) yang dilaksanakan dalam dua siklus. Teknik pengumpulan data yang digunakan adalah tes hasil belajar. Analisis data yang digunakan adalah rumus daya serap individu dan persentase daya serap klasikal. Hasil penelitian membuktikan bahwa terjadi peningkatkan hasil belajar siswa menggunakan model role playing pada materi seni rupa dua dimensi di SMAN 1 Labuhan Deli. Penelitian ini menyarankan agar guru menggunakan model pembelajaran yang mendukung hasil belajar siswa, salah satunya yaitu model role playing yang mempunyai berbagai kelebihan dan keunikan.
\end{abstract}

Kata Kunci: seni rupa, role playing.

\begin{abstract}
Arts and Culture Education develops students' sense of taste, creativity, and aesthetic tastes in art, develops ethics, social awareness and cultural awareness of students in social life, and a love of Indonesian culture. One of the cultural art materials learned for the Upper Middle School level about two-dimensional art. But students in class X IIS 1 of SMA Negeri 1 Labuhan Deli increased the difficulty of learning two-dimensional art results to be low. Therefore this research was conducted which was intended to improve student learning outcomes using the Role Playing model. This research is a classroom action research (CAR) conducted in two cycles. The data collection technique used is a test of learning outcomes. Analysis of the data used is the equation of individual absorption and the percentage of classical absorption. The results of the study prove that an increase in student learning outcomes using role playing models in two-dimensional art material at SMAN 1 Labuhan Deli. This study suggests that teachers use learning models that support student learning outcomes, one of which is role playing models that has various advantages and uniqueness.
\end{abstract}

Keywords: fine art, role playing.

\section{PENDAHULUAN}

Pendidikan Seni Budaya berfungsi mengembangkan kepekaan rasa, kreativitas,dan cita rasa estetis siswa dalam berkesenian, mengembangkan etika, kesadaran sosial dan kesadaran kultural siswa dalam kehidupan bermasyarakat, serta rasa cinta terhadap kebudayaan Indonesia. Mata pelajaran Seni Budaya meliputi bidang Seni Rupa, Seni Musik, Seni Tari dan Seni Teater, masing-masing bidang seni tersebut memiliki substansi, ciri-ciri pembelajaran dan materinya sendiri. Pendidikan Seni Budaya diberikan di sekolah karena keunikan yang terletak pada pemberian pengalaman estetik dalam bentuk kegiatan berekspresi dan berapresiasi melalui pendekatan "Belajar dengan seni, belajar melalui seni dan belajar tentang seni”. Mata pelajaran Seni Budaya memiliki peranan dalam pembentukan pribadi peserta didik yang harmonis dengan memperhatikan kebutuhan perkembangan anak dalam mencapai multi kecerdasan yang terdiri atas kecerdasan intrapersonal, interpersonal, visual spasial, musikal, linguistik, logik matematik, naturalis serta kecerdasan adversitas, kecerdasan kreativitas, kecerdasan spiritual dan moral, dan kecerdasan emosional. 
Seni rupa sebagai salah satu bidang liputan dalan Seni Budaya juga memiliki arah kekhususannya sendiri. Dirjen Pendidikan Dasar menjelaskan bahwa seni rupa ruang lingkupnya di dalam pendidikan sekolah mencakup kemampuan untuk mengapresiasi dan mengkreasikan karya seni rupa. Salah satu materi Seni Budaya yang dpelajari untuk tingkat Sekolah Menengah Atas adalah tentang seni rupa dua dimensi yang meliputi: (a) Mengidentifikasi jenis karya seni rupa dua dimensi; (b) Mengidentifikasi unsur-unsur rupa dan prinsip penataannya dalam karya seni rupa dua dimensi; (3) Mengidentifikasi bahan media dan teknik berkarya seni rupa dua dimensi; (4) Membandingkan unsur-unsur rupa dan prinsip penataannya dalam karya seni rupa dua dimensi; dan (5) Memilih bahan, media, dan teknik dalam proses berkarya seni rupa dua dimensi. Seni rupa dua dimensi tersebut merupakan materi Seni Budaya yang dipelajari untuk siswa kelas $\mathrm{X}$ di tingkat SMA pada semester ganjil. Sama dengan pembelajaran yang lain pada umumnya, tentu terdapat kesulitan untuk mencapai standar kelulusan yang ingin dicapai. Kesulitan tersebut ditimbulkan oleh berbagai masalah yang ada pada siswa kelas X IIS 1 SMA Negeri 1 Labuhan Deli. Masalahnya antara lain dijabarkan sebagai berikut: 1) Sulitnya menanamkan nilai seni pada siswa, 2). Globalisasi berpengaruh pada sikap siswa ketika belajar, 3). Penjelasan yang diberikan guru, kebanyakan tidak mampu diikuti, 4). Motivasi belajar rendah, dan 5). Suasana belajar yang kurang menarik perhatian siswa.

Berdasarkan permasalahan tersebut maka peneliti mengadakan perbaikan pembelajaran materi Seni rupa dua dimensi dalam mata pelajaran Seni Budaya, dimana guru mengadakan perbaikan dengan menerapkan model role playing. Model role playing (bermain peran) adalah cara penguasaan bahan-bahan pelajaran melalui pengembangan imajinasi dan penghayatan yang dimiliki oleh setiap siswa. Model role playing ini merupakan kegiatan simulasi yang diarahkan untuk mengkreasikan peristiwa-peristiwa yang berkaitan dengan materi pelajaran. Masingmasing siswa disini akan berperan menjadi beraneka ragam karya seni rupa dua dimensi dan saling berdialog sambil menjelaskan keunikan dirinya mulai dari media, teknik, hingga makna yang terkandung di dalamnya. Hal ini tentu akan lebih memudahkan siswa dalam memahami dan menghayati tentang materi Seni rupa dua dimensi.

Berdasarkan uraian di atas, maka dilakukan penelitian yang berjudul: Meningkatkan Hasil Belajar Siswa Menggunakan Model Role Playing Pada Materi Seni
Gorga : Jurnal Seni Rupa

Volume 10 Nomor 01 Januari-Juni 2021

p-ISSN: 2301-5942 | e-ISSN: 2580-2380

rupa dua dimensi di SMAN 1 Labuhan Deli. Adapun rumusan masalah yang diteliti, yaitu: Apakah terjadi peningkatkan hasil belajar siswa menggunakan model role playing pada materi seni rupa dua dimensi di SMAN 1 Lbuhan Deli?

\section{KAJIAN TEORI}

\section{Hasil Belajar}

Menurut Bloom yang direvisi Anderson \& Britton (2000) menyatakan hasil belajar dibagi atas tiga kawasan yaitu kognitif, efektif dan psikomotorik. Kawasan kognitif terdiri dari enam jenis perilaku yaitu: (1) ingatan mencakup kemampuan mengingat tentang hal yang telah dipelajari dan tersimpan dalam ingatan, pengetahuan konsep, pengetahuan prosedur, dan pengetahuan metakognitif; (2) pemahaman, mencakup kemampuan menangkap arti dan makna dari pesan, pembicaraan, tulisan dan grafik, berkaitan dengan pemahaman fakta dan pengetahuan konsep; (3) penerapan mencakup kemampuan menerangkan atau menggunakan, prosedur untuk mengahadapi situasi yang baru, berkaitan dengan pengetahuan prosedural; (4) analisis mencakup kemampuan merinci suatu kesatuan ke dalam bagian-bagian sehingga struktur keseluruhan dapat dipahami dengan baik, berkaitan dengan pengetahuan konsep; (5) evaluasi mencakup kemampuan membentuk pendapat tentang beberapa hal berdasarkan kriteria dan standart tertentu, berkaitan dengan pengetahuan prosedural dan pengetahuan meta kognitif; (6) kreatifitas mencakup kemampuan menggabungkan beberapa bagian menjadi suatu bentuk yang koheren atau berfungsi secara menyeluruh, mengorganisasikan bagian-bagian menjadi sebuah pola atau struktur yang baru, berkaitan dengan pengetahuan konsep.

Untuk mengetahui berbagai faktor yang mempengaruhi ketercapaian tujuan dari suatu proses belajar, Angkowo \& Kosasih (2007) menuturkan bahwa hasil belajar siswa dipengaruhi oleh dua faktor utama yaitu faktor yang datang dari dalam diri siswa dan faktor yang datang dari luar diri siswa atau lingkungan. Faktor dari dalam diri siswa menyangkut kemampuan yang dimilik siswa sebesar $70 \%$ dan faktor lingkungan sebesar $30 \%$. Dalam pernyataan lebih lanjut, Angkowo dan Kosasih berpendapat bahwa hasil belajar siswa dipengaruhi oleh lima faktor, yaitu: (1) faktor bakat belajar; (2) faktor waktu yang tersedia untuk belajar; (3) faktor kemampuan individu; (4) faktor kualitas pembelajaran; (5) faktor lingkungan.

Menurut Rohani (2004) salah satu faktor eksternal atau di luar diri siswa yang memiliki pengaruh terhadap pencapaian hasil belajar yang optimal adalah media 
pembelajaran, bahwa segala daya yang dapat dipergunakan untuk kepentingan proses / aktivitas belajar baik secara langsung maupun secara tidak langsung, di luar diri siswa yang melengkapi yang melengkapi diri mereka pada saat pembelejaran berlangsung disebut sebagai sumber belajar. Pernyataan senada juga dikemukakan oleh Slameto (2003) bahwa ada dua faktor yang mempengaruhi hasil belajar yaitu faktor dalam (internal) dan faktor luar (eksternal). Faktor internal adalah faktor yang datangnya dari dalam diri siswa itu sendiri, yang meliputi pengamatan, fantasi, perasaan, kecerdasan, bakat, minat dan perhatian. Pengamatan anak akan mempengaruhi hasil belajar, namun hasil pengamatan itu ditentukan juga oleh keadaan fisik anak tersebut. Fantasi adalah daya jiwa untuk menciptakan tanggapan-tanggapan atas kesan-kesan yang baru dan dengan bantuan tanggapan yang sudah ada. Perasaan merupakan daya yang sangat penting dalam diri siswa, perasaan mencerminkan kepribadian seseorang dengan dunia luar. Biasanya perasaan berwujud senang atau tidak senang, gembira atau sedih, simpati atau antipati, suka atau benci terhadap pelajaran yang diikutinya.

Mata pelajaran Seni Budaya sebagaimana yang diamanatkan dalam Peraturan Pemerintah Republik Indonesia Nomor 19 tahun 2005 tentang Standar Nasional Pendidikan, di dalam mata pelajaran Seni Budaya, aspek budaya tidak dibahas secara tersendiri tetapi terintegrasi dengan seni. Menurut Yoyok (2008) Pendidikan Seni Budaya diajarkan di sekolah karena keunikan, kebermaknaan, dan kebermanfaatan terhadap kebutuhan perkembangan peserta didik, yang terletak pada pemberian pengalaman estetik dalam bentuk kegiatan berekspresi/berkreasi dan berapresiasi melalui pendekatan: "belajar dengan seni," "belajar melalui seni" dan "belajar tentang seni." Peran ini tidak dapat diberikan oleh mata pelajaran lain.

Fauzi (2015) menjelaskan bahwa mata pelajaran Seni Budaya bertujuan untuk menumbuhkembangkan kepekaan rasa estetik dan artistik, sikap kritis, apresiatif dan kreatif pada diri setiap peserta didik secara menyeluruh. Sikap ini hanya mungkin tumbuh jika dilakukan serangkaian proses aktivitas berkesenian pada peserta didik. Mata pelajaran seni budaya memiliki tujuan khusus yaitu: menumbuhkembangkan sikap toleransi, menciptakan demokrasi yang beradab, menumbuhkan hidup rukun dalam masyarakat majemuk, mengembangkan kepekaan rasa dan keterampilan, menerapkan teknologi dalam berkreasi, menumbuhkan rasa cinta budaya dan menghargai warisan budaya Indonesia; dan membuat pergelaran dan pameran karya seni.
Berdasarkan uraian tentang hakikat belajar dan hasil belajar Seni Budaya di atas, maka dapat disimpulkan bahwa hasil belajar Seni Budaya adalah kemampuan siswa dalam menguasai kompetensi-kompetensi yang diharapkan di dalam mata pelajaran Seni Budaya. Kegiatan pembelajaran dinyatakan berhasil bila terjadi perubahan tingkah laku pada diri siswa baik itu peningkatan kemampuan, kualitas, kecakapan, pengetahuan, sikap, kebiasaan, pemahaman, keterampilan, daya pikir, dan kemampuan-kemampuan yang lain yang berkaitan dengan mata pelajaran Seni Budaya.

Salah satu materi dari mata pelajaran Seni Budaya yang dpelajari untuk tingkat Sekolah Menengah Atas adalah seni rupa dua dimensi. Seni rupa dua dimensi adalah karya seni rupa yang memiliki batas dua sisi, yaitu sisi panjang dan sisi lebar. Seni rupa dua dimensi tidak memiliki ruang karena tidak memiliki ketebalan atau ketinggian. Contoh karya seni rupa dua dimensi dalam kehidupan sehari-hari bisa di lihat pada dekorasi dinding.

Unsur-unsur yang ada pada seni rupa dua dimensi wajib untuk di mengerti oleh seorang seniman agar nanti akan mendapatkan hasil karya yang memuaskan. Jika dilihat dari dimensinya maka karya seni rupa dibagi menjadi dua bagian yaitu: Karya seni rupa dua dimensi yang mempunya dua ukuran juga dan karya seni rupa tiga di mensi yang memiliki tiga ukuran atau memiliki ruangan.

Jika di lihat dari fungsinya maka karya seni rupa juga ada yang di buatan dengan memberikan pertimbangan utama yaitu untuk memenuhi fungsi-fungsi praktis. Karya seni rupa seperti ini bisa di kategorikan kedalam jenis karya seni rupa terapan (applied art). Dalam pembuatan karya seni rupa terapan ini maka biasanya melalui beberapa proses seperti proses perancangan desain. Untuk memberikan pertimbangan aspek-aspek dalam karya seni rupa terapan juga memiliki fungsi untuk memperindah bentuk dan tampilan dari sebuah benda dan meningkatkan kenyamanan bagi penggunanya. Berdasarkan karakteristik diatas maka kita semua akan mengenal berbagai macam jenis karya seni rupa seperti: seni lukis, seni patung, seni grafis, seni kriya dan desain. Sehingga unsur-unsur seni rupa yaitu: a). Titik: unsur yang paling kecil dari dasar seni rupa. Akan tetapi titik juga menjadi salah satu pusat perhatian maka apabila titik tersebut berkumpul dan dengan warna yang berbeda.

Titik yang bentuknya besar maka di sebut dengan bintik, b). Garis: sebuah goresan atau penbatas dari satu 
benda dengan benda yang lainnya, bidang, warna, ruangan, texture, dan lain sebagainya. Garis akan mempunyai dimensi yaitu jika memanjang dan memiliki arah yang jelas. Garis akan memberikan kesan-kesan kepada lukisan seperti ide, gerakan, simbol, kode tertentu dan lain sebagainya. Garis ini bisa di manfaatkan dalam desain untuk memberikan tampilan dan kesan tertentu. Seperti halnya untuk menciptakan kesan yang kuat pada lukisan, simple, megah dan lain sebagainya, c). Bidang: salah satu unsur yang akan terbentuk dari beberapa gari yang saling terhubung dengan garis yang lain nya. Bidang memiliki dimensi yang panjang dan juga lebar. Sehingga hasil dari kumpulan bidang akan saling berhubungan dan bisa membentuk suatu bangunan atau suatu bentuk yang memiliki volume. Unsur seni rupa dua dimensi yang lainnya yaitu raut.

Raut adalah potongan yang terlihat dari suatu objek. Jika disebut dengan bidang, maka bidang adalah istilah yang sering di gunakan untuk menunjukkan suatu bentuk benda yang cenderung dengan pipih atau datar dan sedangkan bangunan atau bentuk akan lebih menunjukkan kepada wujud benda yang sudah memiliki volume, d). Bentuk: bentuk plastis atau bangunan. Bentuk plastis adalah bentuk dari suatu benda yang bisa di lihat dan di raba karena memiliki unsur nilai dari suatu benda itu, contohnya lemari. Lemari yang di tempatkan di dalam ruangan tidak hanya berbentuk segi empat akan tetapi memiliki nilai dan peran tersendiri. Bangunan adalah bentuk dari suatu benda yang hanya terlihat polos sama halnya dengan yang di lihat oleh mata, hanya sekedar untuk menunjukkan sifatnya berbentuk persegi, bulat, ornamentak, tak teratur dan lain sebagainya, e). Tekstur: sifat dari sebuah permukaan benda. Sifat permukaan sebuah benda yang dapat berkesan kasar, halus, kusam, licin, mengkilap, berpori dan lain sebagainya.

Kesan yang ada di tekstur ini bisa kita rasakan dengan dilihat dan juga dengan disentuh atau rabaan, dan f). Warna: Dalam karya seni rupa dua dimensi ada pendekatan yang untuk mempelajari tentang warna, salah satu dari teori warna yaitu berdasarkan pigmen warna atau berdasarkan gothe yaitu butiran halus dari warna. Ada beberapa istilah di dalam teori warna pigmen, yaitu sebagai berikut ini: Warna Primer yaitu warna pokok atau warna dasar yang tidak akan bisa di campur dengan warna yang lain nya. Contoh dari warna primer adalah: Merah, Kuning dan Biru. Warna sekunder yaitu warna yang di hasilkan dari beberapa campuran warna primer. Contoh dari warna sekunder adalah: Ungu, Oranye, dan Hijau. Sedangkan warna tersier yaitu warna yang di hasilkan dari ke dua warna sekunder.

\section{1). Gelap Terang}

Dalam karya seni rupa dua dimensi juga memiliki gelap dan terang yang juga memiliki beberapa fungsi yaitu untuk memberikan kesan ruang atau kedalaman, memberikan kesan tiga dimensi pada suatu benda yang ada, dan juga memberikan perbedaan kontras. Di dalam karya seni rupa dua dimensi, gelap terang juga bisa terjadi karena intensitas warna atau juga karena campuran warna hitam dan juga putih.

\section{2). Ruang dan Kedalaman}

Ruang dan kedalaman dalam karya seni rupa dua dimensi yaitu ruangan yang sangat bergantung pada luas bidang gambar yang ada. Unsur ruang yang ada pada karya seni dua dimensi yaitu memiliki sifat yang semu atau maya akrena unsur dari ruang ini hanya di ciptakan melalui kesan dan juga penggambaran yang datar, pipih, menjorok, jauh, cembung, cekung dan lain sebagainya.

\section{3). Media}

Media adalah salah satu alat yang sering di gunakan untuk menghasilkan karya. Pensil merupakan salah satu media yang paling sering digunakan dalam berkarya seni rupa dua dimensi. Pensil dibuat dengan campuran grafit dan tanah liat, pensil ini sangat fundamental dalam banyak pembuatan karya seni rupa. Karya seni yang dihasilkan dengan menggunakan alat berupa pensil dapat menghasilkan misalnya sebuah sketsa atau lukisan. Konte juga termasuk media yang sering digunakan dalam banyak karya seni rupa dua dimensi, konte bertektur halus dan berwarna sangat hitam atau bisa dikatakan memiliki warna yang hitam legam.

Selain pensil dan konte, ada jenis alat yang juga tidak kalah sering digunakan, yaitu pensil warna dan krayon. Pensil warna banyak digunakan untuk membuat karya berupa lukisan, pensil warna terdiri dari berbagai macam warna-warna dan memiliki tektur lembut. Pensil warna merupakan alat melukis yang dikenal banyak kalangan karena penggunaanya terbilang mudah. Sedangkan krayon merupakan bahan atau alat yang digunakan untuk membuat karya seni dua dimensi yang memiliki banyak ragam warna, krayon terbuat dari unsur lilin dan kapur sehingga penggunaanya terbilang mudah dan sangat akrab bagi pelukis pemula.

Pena juga alat yang digunakan untuk menunjang sebuah karya seni rupa dua dimensi yang bahannya terbuat dari tinta, dimana tinta yang ada dalam pena 
sering hanya didominasi tiga warna yaitu warna hitam, biru, dan merah. Cat air juga merupakan bahan yang sangat familiar di telingga para pelukis bahkan untuk para pelukis pemula, cat air sangat digemari karena penggunaanya yang mudah dan menimbulkan hasil karya yang cenderung bersifat lukisan klasik, cat air ini banyak digunakan para seniman seni rupa dua dimensi baik diatas media. Cat air memiliki sifat transparan dan mudah larut. Cat minyak merupakan salah satu alat yang digunakan seorang seniman lukis untuk membuat karyanya diatas media kanvas, cat minyak ini merupakan alat yang memiliki tingkat kesulitan yang tidak mudah dimana untuk melihat hasil karyanya dibutuhkan waktu beberapa hari karena sifatnya yang membutuhkan waktu lama untuk kering. Akan tetapi cat minyak ini sanga disukai karena pelukis dapat menggambarkan imajinasinya lewat perpaduan warna yang didapatnya secara ekslusif.

\section{Model Role Playing}

Komaruddin (2000) memaparkan bahwa model secara umum dapat dipahami sebagai: (1) suatu tipe desain; (2) suatu deskripsi atau analogi yang digunakan untuk membantu proses visualisasi sesuatu yang tidak dapat dengan langsung diamati; (3) suatu sistem asumsiasumsi, data-data dan inferensi-infrensi yang dipakai untuk menggambarkan secara sistematis suatu objek atau peristiwa; (4) suatu desain yang disederhanakan dari suatu sistem kerja, suatu terjemahan realitas yang disederhanakan; (5) suatu deskripsi dari suatu sistem yang mungkin atau imajiner; dan (6) penyajian yang diperkecil agar dapat menjelaskan dan menunjukkan sifat bentuk aslinya.

Menurut Rahmat (2008) bahwa model diartikan sebagai representasi suatu fenomena, baik nyata maupun abstrak dengan menonjolkan unsur-unsur terpenting fenomena tersebut. Sama halnya dengan yang dikemukakan oleh Sapriya (2002) bahwa: model ini dapat berupa bentuk asli dari suatu benda, benda yang pernah ada, benda yang akan dibuat atau benda yang seharusnya ada, atau benda yang mungkin ada. Model ini dapat berupa maket fisik seperti model skala rumah, kapal gedung, dan lain-lain. Model dapat juga berupa tulisan seperti cetak biru (blue print). Adapun fungsi model ini adalah digunakan untuk memahami sesuatu yang diwakili seperti apa atau bagaimana cara kerja dari sesuatu.

Berdasarkan pendapat di atas dapat peneliti kemukakan bahwa, model merupakan wakil atau representasi dari suatu fenomena baik nyata maupun abstrak dan berfungsi untuk membantu dalam memahami suatu fenomena atau suatu benda yang diwakili tersebut.
Dalam pembelajaran di kelas, seorang guru hendaknya mahair menterjemahkan hasil belajar pembelajaran menjadi menarik bagi peserta didik, yang biasanya diperlukan sesuatu yang berfungsi sebagai wakil atau representasi.

Uno (2009) mengartikan model pembelajaran adalah pola yang digunakan dalam pembelajaran.setiap model pembelajaran memandu bagaimana mendesain pembelajaran serta membantu peserta didik dalam mencapai tujuan belajar. Dari setiap pemilihan model pembelajaran yang memberikan pola pembelajaran dalam membantu peserta didik dalam mencapai tujuan pembelajaran, perlu diperhatikan faktor kepentingan guru untuk menjalankan proses pembelajaran dan faktor kesesuaian dengan struktur, suasana dan lingkungan yang dihadapi peserta didik yang terkait dalam setiap pemilihan model tersebut.

Menurut Joyce \& Weil (1992) bahwa Model pembelajaran adalah suatu perencanaan atau suatu pola yang digunakan sebagai pedoman dalam merencanakan pembelajaran di kelas atau pembelajaran dalam tutorial dan untuk menentukan perangkat-perangkat termasuk di dalamnya buku, film, komputer dan kurikulum. Model diartikan sebagai kerangka konseptual yang digunakan sebagai pedoman dalam melakukan kegiatan.

Reigeluth (1983) menyatakan bahwa model pembelajaran adalah seperangkat lengkap komponen strategi, yang merupakan model lengkap dengan semua bagiannya yang dijelaskan secara rinci. Model pembelajaran dibagi menjadi dua yaitu: (1) model pembelajaran yang bersifat fix (pasti), artinya model ini mempreskripsikan variabel-variabel model yang sama yang akan dilakukan / terjadi pada siswa saat pembelajaran, dan (2) adaptif (menyesuaikan) artinya model ini mempreskripsikan variabel-variabel model yang berbeda bergantung pada respon tindakan siswa.

Suprijono (2010) mendefenisikan model pembelajaran sebagai pola yang digunakan sebagai pedoman dalam merencanakan pembelajaran di kelas maupun tutorial. Richey (1986) mengemukakan bahwa model pembelajaran adalah gambaran yang ditimbulkan dari kenyataan yang mempunyai susunan dari urutan tertentu. Menurutnya model dapat digunakan untuk mengorganisasikan pengetahuan dari berbagai sumber kemudian dipakai sebagai stimulus untuk mengembangkan hipotesis dan membangun teori ke dalam istilah/ keadaan yang konkrit untuk menerapkannya pada praktek atau menguji teori. Model pembelajaran dapat dijadikan sebagai pola 


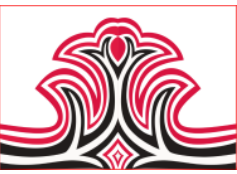

pilihan, artinya para guru boleh memilih pembelajaran yang sesuai dan efisien untuk mencapai tujuan. Pemilihan model pembelajaran tertentu akan berpengaruh terhadap kegiatan-kegiatan yang akan dilakukan peserta didik maupun guru dalam proses pembelajaran yang akan berlangsung. Dengan demikian dapat disimpulkan bahwa, model pembelajaran merupakan acuan atau bungkus/bingkai dari penerapan suatu pendekatan, model dan teknik pembelajaran yang diterapkan oleh seorang guru dalam mencapai proses pembelajaran.

Menurut Mulyasa (2005) pembelajaran dengan role playing ada tujuh tahap yaitu pemilihan masalah, pemilihan peran, menyusun tahap-tahap bermain peran, menyiapkan pengamat, tahap pemeranan, diskusi dan evaluasi serta pengambilan keputusan. Pada tahap pemilihan masalah, guru mengemukakan masalah yang diangkat dari kehidupan peserta didik agar mereka dapat merasakan masalah itu dan terdorong untuk mencari penyelesainnya. Tahap pemilihan peran memilih peran yang sesuai dengan permasalahan yang akan dibahas, mendeskripsikan karakter dan apa yang harus dikerjakan oleh para pemain. Selanjutnya menyusun tahap-tahap bermain peran. Dalam hal ini guru telah membuat dialog tetapi siswa bisa menambah dialog sendiri. Tahap berikutnya adalah menyiapkan pengamat. Pengamat dari kegiatan ini adalah semua siswa yang tidak menjadi pemain atau pemeran. Setelah semuanya siap maka dilakukan kegiatan pemeranan. Pada tahap ini semua peserta didik mulai bereaksi sesuai dengan peran masing-masing sesuai yang terdapat pada skenario bermain peran. Dalam hal ini guru menghentikan pada saat terjadinya pertentangan agar didiskusikan.

Model role playing atau bermain peran ini merupakan pembelajaran yang lebih menekankan pada permainan gerak dan siswa biasanya dilatih untuk memahami, memperagakan setiap peran-peran yang diperankan untuk selanjutnya, biasanya siswa ditugaskan untuk memberikan penilaian baik kekurangan atau kelebihan dari peran yang dimainkan ataupun juga jalan cerita yang diperankannya. Selain penilaian terhadap peran, penilaian terhadap jalan cerita dalam role playing tersebut biasanya dijadikan bahan refleksi dalam model role playing misalnya menentukan apa isi cerita tersebut, hikmah yang didapat dalam ceritanya dan lain-lain.

Menurut A'la (2011) model role playing (bermain peran) adalah merupakan cara penguasaan bahanbahan pelajaran melalui pengembangan imajinasi dan penghayatan yang dimiliki oleh setiap siswa.
Gorga : Jurnal Seni Rupa

Volume 10 Nomor 01 Januari-Juni 2021

p-ISSN: 2301-5942 | e-ISSN: 2580-2380

Pengembangan imajinasi dan penghayatan dilakukan siswa dengan memerankan sebagai tokoh hidup atau benda mati. Permainan ini umumnya dilakukan lebih dari satu orang, itu bergantung kepada apa yang diperankan. Menurut Sanjaya (2008) model role playing ini merupakan sebagian dari simulasi yang diarahkan untuk mengkreasikan peristiwa-peristiwa aktual atau kejadian-kejadian yang mungkin muncul pada masa mendatang. Ngalimun (2014) Sintaks dari model pembelajaran ini adalah: guru menyiapakan skenario pembelajaran, menunjuk beberapa siswa untuk mempelajari skenario tersebut, pembentukan kelompok siswa, penyampaian kompetensi, menunjuk siswa untuk melakonkan skenario yang telah dipelajarinya, kelompok siswa membahas peran yang dilakukan oleh pelakon, presentasi hasil kelompok, bimbingan kesimpulan dan refleksi.

Langkah-langkah atau prosedur dalam pelaksanaan model role playing ini Shoimin (2014) adalah: (1) guru menyusun/ menyiapkan skenario yang akan ditampilkan; (2) menunjuk beberapa siswa untuk mempelajari skenario dua hari atau beberapa hari sebelum KBM (kegiatan belajar mengajar) guna mempersiapkan peran yang terdapat dalam skenario tersebut; (3) guru membentuk kelompok siswa yang anggotanya 5 orang atau sesuai dengan kebutuhan; (4) memberikan penjelasan tentang kompetensi yang ingin dicapai dalam meteri tersebut; (5) memanggil para siswa yang sudah ditunjuk untuk melakonkan skenario yang sudah dipersiapkan sebelumnya; (6) masingmasing siswa duduk dikelompoknya, masing-masing sambil memperhatikan mengamati skenario yang sedang diperagakan; (7) setelah selesai dipentaskan, masing-masing siswa diberikan kertas sebagai lembar kerja untuk membahas skenario tersebut. Misalnya menilai peran yang dilakonkan, mencari kelemahan dan kelebihan dari peran tersebut atau pun alur/jalan ceritanya; (8) masing-masing kelompok menyampaikan hasil dan kesimpulannya; (9) guru memberikan kesimpulan secara umum atau mengevaluasi seluruh kegiatan; (10) evaluasi/ refleksi; (11) penutup. (Uno, 2003) mengemukakan prosedur bermain peran terdiri ata sembilan langkah, yaitu: a). Persiapan atau pemanasan. Guru berupaya memperkenalkan siswa pada permasalahan yang mereka sadari sebagai suatu hal yang baik semua orang perlu mempelajari dan menguasainya. Hal ini bisa muncul dari imajinasi siswa atau sengaja disiapkan guru. Sebagai contoh, guru menyediakan suatu cerita untuk dibaca di depan kelas. Pembaca cerita jika dilema atau masalah dalam cerita menjadi jelas. Kemudian dilanjutkan dengan pengajuan pertanyaan oleh guru yang membuat siswa berpikir tentang hal tersebut. 
Gorga : Jurnal Seni Rupa

Volume 10 Nomor 01 Januari-Juni 2021

p-ISSN: 2301-5942 | e-ISSN: 2580-2380

b). Memilih pemain (partisipan). Siswa dan guru membahas karakter dari setiap pemain dan menentukan siapa yang akan memainkannya. Dalam pemilihan pemain, guru dapat memilih siswa yang sesuai untuk memainkannya (jika siswa pasif atau diduga memiliki keterampilan berbicara yang rendah) atau siswa sendiri yang mengusulkannya, c). Menata panggung (ruang kelas). Guru mendiskusikan dengan siswa dimana dan bagaimana peran itu akan dimainkan serta apa saja kebutuhan yang diperlukan, d). Menyiapkan pengamat (observer). Guru menunjukkan siswa sebagai pengamat, namun demikian penting untuk dicatat bahwa pengamat disini harus juga terlibat aktif dalam permainan peran, e). Memainkan peran. Permainan peran dilaksanakan secara spontan. Pada awalnya akan banyak siswa yang masih bingun memainkan perannya atau bahkan tidak sesuai dengan peran yang seharusnya ia lakukan. Bahkan mungkin ada yang memainkan peran yang bukan perannya. Jika permainan peran sudah terlalu jauh keluar jalur, guru dapat menghentikannya untuk segera masuk ke langkah berikutnya, f). Diskusi dan evaluasi. Guru bersama dengan siswa mendiskusikan permainan tadi dan melakukan evaluasi terhadap peran-peran yang dilakukan. Usulan perbaikan akan muncul, mungkin ada siswa yang meminta untuk berganti peran bahkan alur ceritanya akan sedikit berubah, g). Bermain peran ulang. Permainan peran ulang seharusnya berjalan lebih baik, siswa dapat memainkan perannya lebih sesuai dengan skenario, h). Diskusi dan evaluasi kedua. Pembahasan diskusi dan evaluasi kedua diarahkan pada realitas. Mengapa demikian? Pada saat permainan peran dilakukan benyak peran yang melampaui batas kenyataan, sebagai contoh seorang siswa memainkan peran sebagai pembeli, ia membeli barang dengan harga yang tidak realitas. Hal ini menjadi bahan diskusi, dan i). Berbagai pengalaman dan diskusi. Siswa diajak untuk berbagi pengalaman tentang tema permainan peran yang telah dilakukan dan dilanjutkan dengan kesimpulan. Misalnya siswa akan berbagi pengalaman tentang bagaimana ia dimarahi habishabisan oleh ayahnya. Kemudian guru membahas bagaimana sebaiknya siswa menghadapi situasi tersebut. Seandainya jadi ayah dari siswa tersebut, sikap seperti apa sebaiknya dilakukan. Dengan cara ini, siswa akan belajar tentang kehidupan.

Menurut Istarani (2012) penggunaan model role playing dilakukan yaitu: (1) apabila ingin melatih para siswa agar mereka dapat menyelesaikan masalah yang bersifat sosial psikologis; (2) apabila ingin melatih para siswa agar mereka dapat bergaul dan memberi pemahaman terhadap orang lain serta masalahnya; (3) apabila ingin menerangkan suatu peristiwa yang didalamnya menyangkut banyak orang. Setiap model pembelajaran tidak ada yang sempurna, karena masingmasing memiliki kelemahan dan kelebihannya tersendiri.

Shoimin (2014) memaparkan kelemahan dan kelebihan dari model role playing ini diantaranya adalah: kelebihan model role playing: (1) melibatkan seluruh siswa berpartisipasi, mempunyai kesempatan untuk memajukan kemampuannya dalam bekerja sama; (2) siswa juga dapat belajar menggunakan bahasa dengan baik dan benar; (3) siswa bebas mengambil keputusan dan berekspresi secara utuh; (4) permainan merupakan penemuan yang mudah dan dapat digunakan dalam situasi dan waktu yang berbeda; (5) guru dapat mengevaluasi pengalaman siswa melalui pengamatan pada waktu melakukan permainan; (6) dapat berkesan dengan kuat dan tahan lama dalam ingatan siswa. Disamping merupakan pengaman yang menyenangkan yang sulit untuk dilupakan; (7) sangat menarik bagi siswa, sehingga memungkinkan kelas menjadi dinamis dan penuh antusias; (8) membangkitkan gairah dan semangat optimisme dalam diri siswa serta menumbuhkan rasa kebersamaan dan kesetiakawanan sosial yang tinggi; (9) dapat menghayati peristiwa yang berlangsung dengan mudah, dan dapat memetik butirbutir hikmah yang terkandung di dalamnya dengan penghayatan siswa sendiri; (10) dimungkinkan dapat meningkatkan kemampuan profesional siswa, dan dapat menumbuhkan/ membuka kesempatan bagi lapangan kerja.

Kelemahan model role playing: (1) metode ermain peranan memerlukan waktu yang relatif panjang / banyak; (2) memerlukan kreativitas dan daya kreasi yang tinggi dari pihak guru maupun murid. Dan ini tidak semua guru memilikinya; (3) kebanyakan siswa yang ditunjuk sebagai pemeran merasa malu untuk memerankan suatu adegan tertentu; (4) apabila pelaksanaan sosiodrama dan bermain peran mengalami kegagalan, bukan saja dapat memberi kesan kurang baik, tetapi sekaligus berarti tujuan pengajarn tidak tercapai; (5) tidak semua materi pelajaran dapat disajikan melalui model ini; (6) sebagian besar anak yang tidak ikut drama mereka menjadi kurang aktif; (7) memerlukan tempat yang cukup luas, jika tempat bermain sempit menyebabkan gerak para pemain kurang bebas; (8) kelas lain sering terganggu oleh suara pemain dan penonton yang kadang-kadang bertepuk tangan. Menurut Sagala (2011) ada beberapa cara untuk mengatasi kelemahan-kelemahan pada metode role playing ini diantaranya: a). Guru harus menerangkan kepada siswa, untuk dapat memecahkan masalah hubungan sosial yang aktual ada di masyarakat, b). 
Guru harus dapat memilih masalah yang urgent sehingga menarik minat anak. Ia dapat menjelaskan dengan baik dan menarik, sehingga menarik minat anak, c). Agar siswa memahami peristiwa maka guru harus menceritakan sambil mengatur adegan pertama, dan d). Bobot atau materi bahan ajar yang diperankan harus sesuai dengan waktu yang tersedia.

Berdasarkan uraian di atas dapat disimpulkan bahwa model role playing adalah bentuk pembelajaran dengan cara memberikan peran-peran tertentu serangkaian situasi-situasi belajar kepada siswa dalam bentuk keterlibatan pengalaman sesungguhnya sesuai rancangan guru.

\section{METODE PENELITIAN}

Metode penelitian yang digunakan yaitu penelitian tindakan kelas (PTK). PTK sebagai metode penelitian yang mengkaji dan berupaya menyelesaikan masalah di dalam kelas dengan memberikan suatu tindakan baru. Pelaksanaan PTK sesuai prosedur yang dikemukakan oleh Arikunto (2012) bahwa pelaksanaan PTK terdiri dari beberapa siklus dan setiap siklus mempunyai empat tahapan yaitu: perencanaan, tindakan/observasi, refleksi, dan perbaikan.

Teknik pengumpulan data yang digunakan adalah tes untuk mengukur hasil belajar seni rupa dua dimensi. Analisis data yang digunakan adalah data kuantitatif tes hasil belajar siswa yang digunakan setelah penelitian. Analisis ini dilakukan untuk mengetahui berhasil atau tidaknya tindakan yang dilakukan dalam penelitian ini dengan rumus daya serap individu dan persentase daya serap klasikal.

\section{HASIL DAN PEMBAHASAN}

\section{Hasil}

\section{1). Hasil Belajar Seni rupa dua dimensi} Menggunakan Model Role Playing (Siklus I)

\section{(1). Tahap Perencanaan Siklus I}

Tahap perencanaan dilakukan dengan melakukan beberapa, yaitu: membuat RPP yang menggunakan model Role Playing, mempersiapkan media, bahan ajar dan sumber belajar.

\section{(2). Tahap Tindakan Siklus I}

Tindakan pada siklus I dilaksanakan dengan beberapa tahapan berikut: (1) kegiatan awal meliputi membekali siswa dengan pembahasan seni rupa dua dimensi, apersepsi, dan informasi kegiatan; (2) kegiatan inti meliputi mengamati, tanya jawab, diskusi dan menyimpulkan pendapat; dan (3) kegiatan akhir meliputi umpan balik, pengayaan, dan latihan.

\section{(3). Tahap Observasi Siklus I}

Pengamatan ini dilakukan untuk mengetahui apakah tindakan yang dilakukan memberikan kontribusi terhadap peningkatan hasil belajar siswa atau tidak. Untuk itu diperlukan alat-alat pemantauan dan evaluasi yang tepat dan terinci sehingga dapat digunakan sebagai alat ukur keberhasilan. Pada tahap pengamatan dan evaluasi guru mengumpulkan data menggunakan instrumen yang telah disediakan.

\section{(4). Tahap Refleksi Siklus I}

Pada tahap refleksi dilakukan penentuan hasil belajar siswa meningkat atau tidak. Kegiatan ini dilakukan secara mandiri dan menjadi tanggung jawab peneliti. Hasil yang didapat dari tahap tindakan dan observasi dikumpulkan dan dianalisa pada tahap refleksi sehingga diperoleh kesimpulan dan tindak lanjut yang tepat. Berikut hasil dari tindakan pada siklus I, yaitu pada tabel berikut ini:

Tabel 1. Hasil Belajar pada Siklus I

\begin{tabular}{|c|c|c|}
\hline Nilai KKM & Jumlah Siswa & Persentase \\
\hline$>75$ (tuntas) & 20 & $55,56 \%$ \\
\hline$<75$ (tidak tuntas) & 16 & $44,44 \%$ \\
\hline Jumlah & 36 & $100 \%$ \\
\hline
\end{tabular}

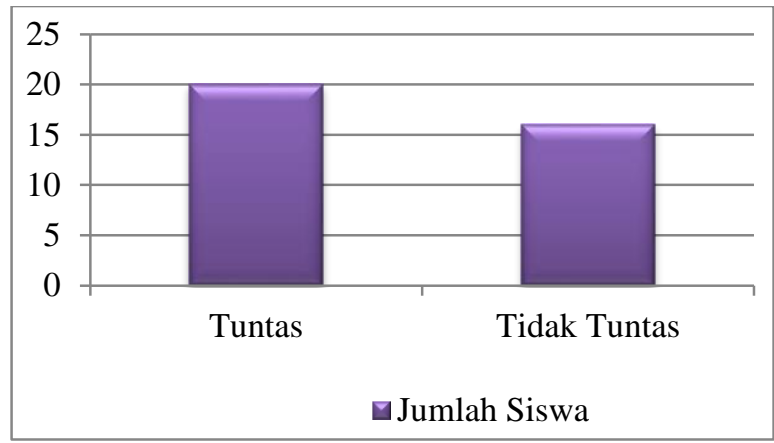

Gambar 1. Hasil Belajar pada Siklus I

Pelaksanaan siklus I, hasil belajar siswa pada materi Seni rupa dua dimensi belum terlihat berhasil. Namun terdapat beberapa peningkatan yang terjadi pada siklus I yaitu: (1) Siswa mulai memahami tentang cara mengidentifikasi jenis karya seni rupa dua dimensi; (2) Siswa lebih termotivasi saat belajar menggunakan model Role Playing dibandingkan pembelajaran sebelumnya; dan (3) Sebagian siswa mulai aktif mengeluarkan pendapatnya tentang jenis karya seni rupa dua dimensi. Kegagalan yang terjadi pada siklus I menyebabkan ketuntasan belajar hanya mencapai $55,56 \%$ sedangkan sisanya sebanyak 44,44\% tidak tuntas belajar. Berikut kegagalan yang terjadi: (1) Ketika guru memberikan pertanyaan, siswa terlihat bingung karena kurang mampu menganalisis arahan guru; (2) Banyak siswa yang tidak fokus ketika guru menjelaskan tentang Seni rupa dua dimensi; dan (3) pengalaman siswa yang sangat sedikit mengenai Seni 
rupa dua dimensi, sehingga siswa kurang aktif dalam belajar.

Berdasarkan uraian di atas, maka dapat ditarik kesimpulan dari hasil refleksi bahwa tindakan pada siklus I belum mencapai target ketuntasan minimal $80 \%$ karena hanya $55,56 \%$ siswa yang memperoleh nilai lebih dari 75 atau tuntas belajar mengenai Seni rupa dua dimensi setelah menerapkan model Role Playing. Dengan demikian, tindakan penerapan model Role Playing dilanjutkan pada Siklus II.

2). Hasil Belajar Seni rupa dua dimensi Menggunakan Model Role Playing (Siklus II)

(1). Tahap perencanaan siklus II

Hasil analisa dan refleksi I maka dibuat kembali rencana tindakan II sebagai upaya mengatasi permasalahan yang belum terselesaikan pada siklus I. Pada tahap ini kegiatan yang dilakukan masih tetap memuat perencanaan tindakan sebagai upaya mengatasi kesulitan siswa dalam mempelajari tentang Seni rupa dua dimensi. Tahap perencanaan dilakukan dengan melakukan beberapa, yaitu: membuat RPP yang menggunakan model Role Playing, mempersiapkan media, bahan ajar dan sumber belajar.

\section{(2). Tahap Tindakan Siklus II}

Pemberian pelaksanaan tindakan II ini merupakan pengembangan dan pelaksanaan dari program perencanaan yang telah disusun. Pada tahap ini diakhiri dengan pemberian tes hasil belajar II yang bertujuan untuk mengetahui sejauh mana peningkatan penguasaan siswa terhadap materi yang diberikan. Tindakan yang dilakukan pada pertemuan 1 dan pertemuan 2 pada siklus II: (1) kegiatan awal meliputi membekali siswa tentang Seni rupa dua dimensi, apersepsi, dan informasi kegiatan; (2) kegiatan inti meliputi mengamati, tanya jawab, menanggapi pendapat teman, mengeluarkan pendapat, membentuk kelompok drama, mengarang dialog peran, berlatih peran, menampilkan peran dan menarik kesimpulan. Kegiatan guru meliputi mengamati kegiatan dan sikap siswa pembelajaran, serta meluruskan dan mengarahkan kesimpulan; dan (3) kegiatan akhir meliputi memberikan umpan balik dan pengayaan.

\section{(3). Tahap Observasi Siklus II}

Pengamatan II dilaksanakan untuk melihat kondisi belajar mengajar sudah terlaksana sesuai program pengajaran ketika tindakan diberikan. Setelah tes hasil belajar II diberikan kepada siswa maka selanjutnya guru menganalisis hasil belajar Seni Budaya setelah dilakukannya pembelajaran menggunakan model role playing. Pada tahap pengamatan dan evaluasi guru
Gorga : Jurnal Seni Rupa

Volume 10 Nomor 01 Januari-Juni 2021

p-ISSN: 2301-5942 | e-ISSN: 2580-2380

melakukan pengumpulan data dengan mempersiapkan instrumen pengumpulan data. Guru berperan sebagai pengamat untuk melihat kekurangan-kekurangan yang terjadi selama proses belajar.

\section{(4). Tahap Refleksi Siklus II}

Pada tahap refleksi dilakukan penentuan hasil belajar siswa meningkat atau tidak. Seluruh data yang diambil dianalisis dan ditarik kesimpulan dari tindakan perbaikan yang telah dilakukan dan dapat diperoleh kesimpulan hasil belajar dari siklus ke siklus II, yaitu pada tabel berikut ini:

Tabel 2. Hasil Belajar pada Siklus II

\begin{tabular}{|c|c|c|}
\hline Nilai KKM & Jumlah Siswa & Persentase \\
\hline$>75$ (tuntas) & 31 & $86,11 \%$ \\
\hline$<75$ (tidak tuntas) & 5 & $13,89 \%$ \\
\hline Jumlah & 36 & $100 \%$ \\
\hline
\end{tabular}

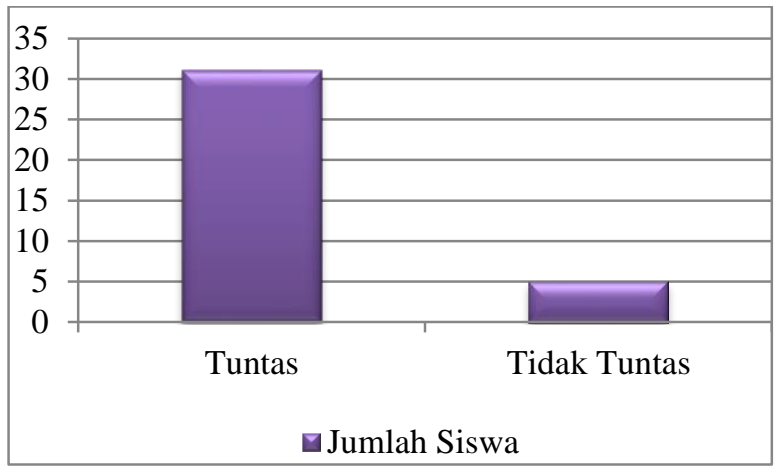

Gambar 2. Hasil Belajar pada Siklus II

Refleksi siklus II ditemukan beberapa kegagalan yang terjadi ketika melaksanakan tindakan, diantaranya: (1) Terdapat siswa yang belum mampu memahami secara baik tentang mengidentifikasi unsur-unsur seni rupa dua dimensi; (2) Terdapat siswa yang kesulitan memahami prinsip penataan dalam karya seni rupa dua dimensi. Pada kegiatan siklus II juga terdapat keberhasilan, yakni: (1) Sebanyak 31 orang $(86,11 \%)$ siswa tuntas belajar; (2) Siswa sudah membuat karya seni rupa dua dimensi sesuai indikator sehingga mendapatkan skor yang tinggi; (3) Kinerja guru semakin baik dalam menerapkan model Role playing ataupun teknik pengelolaan kelasnya sehingga mendukung pencapaian tujuan pembelajaran.

Uraian di atas, maka dapat ditarik kesimpulan dari hasil refleksi bahwa tindakan pada siklus II telah mencapai target ketuntasan minimal $80 \%$ karena terdapat $86,11 \%$ siswa yang memperoleh nilai lebih dari 75 atau tuntas belajar mengenai Seni rupa dua dimensi setelah menerapkan model Role Playing. Dengan demikian, tindakan penerapan model Role Playing berhenti pada Siklus II tanpa dilanjutkan ke siklus III maupun seterusnya. Dari siklus I ke siklus II terdapat 
Gorga : Jurnal Seni Rupa

Volume 10 Nomor 01 Januari-Juni 2021

p-ISSN: 2301-5942 | e-ISSN: 2580-2380

penambahan jumlah siswa yang tuntas belajar yakni dari $55,56 \%$ menjadi $86,11 \%$. Dengan demikian diperoleh kesimpulan akhir dari penelitian ini bahwa terjadi peningkatkan hasil belajar siswa menggunakan model role playing pada materi seni rupa dua dimensi di SMAN 1 Labuhan Deli.

\section{Pembahasan}

Pelaksanaan siklus I, hasil belajar siswa pada materi Seni rupa dua dimensi belum terlihat berhasil. Namun terdapat beberapa peningkatan yang terjadi pada siklus I yaitu: (1) Siswa mulai memahami tentang cara mengidentifikasi jenis karya seni rupa dua dimensi; (2) Siswa lebih termotivasi saat belajar menggunakan model Role Playing dibandingkan pembelajaran sebelumnya; dan (3) Sebagian siswa mulai aktif mengeluarkan pendapatnya tentang jenis karya seni rupa dua dimensi. Kegagalan yang terjadi pada siklus I menyebabkan ketuntasan belajar hanya mencapai $55,56 \%$ sedangkan sisanya sebanyak $44,44 \%$ tidak tuntas belajar. Berikut kegagalan yang terjadi: (1) Ketika guru memberikan pertanyaan, siswa terlihat bingung karena kurang mampu menganalisis arahan guru; (2) Banyak siswa yang tidak fokus ketika guru menjelaskan tentang Seni rupa dua dimensi; dan (3) pengalaman siswa yang sangat sedikit mengenai Seni rupa dua dimensi, sehingga siswa kurang aktif dalam belajar. Dari uraian tersebut, maka dapat ditarik kesimpulan dari hasil refleksi bahwa tindakan pada siklus I belum mencapai target ketuntasan minimal $80 \%$ karena hanya $55,56 \%$ siswa yang memperoleh nilai lebih dari 75 atau tuntas belajar mengenai Seni rupa dua dimensi setelah menerapkan model Role Playing. Dengan demikian, tindakan penerapan model Role Playing dilanjutkan pada Siklus II.

Refleksi siklus II ditemukan beberapa kegagalan yang terjadi ketika melaksanakan tindakan, diantaranya: (1) Terdapat siswa yang belum mampu memahami secara baik tentang mengidentifikasi unsur-unsur seni rupa dua dimensi; (2) Terdapat siswa yang kesulitan memahami prinsip penataan dalam karya seni rupa dua dimensi. Pada kegiatan siklus II juga terdapat keberhasilan, yakni: (1) Sebanyak 31 orang $(86,11 \%)$ siswa tuntas belajar; (2) Siswa sudah membuat karya seni rupa dua dimensi sesuai indikator sehingga mendapatkan skor yang tinggi; (3) Kinerja guru semakin baik dalam menerapkan model Role playing ataupun teknik pengelolaan kelasnya sehingga mendukung pencapaian tujuan pembelajaran. Dari uraian di atas, maka dapat ditarik kesimpulan dari hasil refleksi bahwa tindakan pada siklus II telah mencapai target ketuntasan minimal $80 \%$ karena terdapat $86,11 \%$ siswa yang memperoleh nilai lebih dari 75 atau tuntas belajar mengenai Seni rupa dua dimensi setelah menerapkan model Role Playing. Dengan demikian, tindakan penerapan model Role Playing berhenti pada Siklus II tanpa dilanjutkan ke siklus III maupun seterusnya. Dari siklus I ke siklus II terdapat penambahan jumlah siswa yang tuntas belajar yakni dari $55,56 \%$ menjadi $86,11 \%$. Dengan demikian diperoleh kesimpulan akhir dari penelitian ini bahwa terjadi peningkatkan hasil belajar siswa menggunakan model role playing pada materi seni rupa dua dimensi di SMAN 1 Labuhan Deli.

Peningkatan hasil belajar siswa materi seni rupa dua dimensi terjadi merupakan akibat dari tindakan model role playing yang diterapkan selama dua siklus. Angkowo \& Kosasih (2007) menuturkan bahwa hasil belajar siswa dipengaruhi oleh lima faktor, yaitu: faktor bakat belajar, faktor waktu yang tersedia untuk belajar, faktor kemampuan individu, faktor kualitas pembelajaran, dan faktor lingkungan. Menurut Rohani (2004) salah satu faktor eksternal atau di luar diri siswa yang memiliki pengaruh terhadap pencapaian hasil belajar yang optimal adalah media pembelajaran, bahwa segala daya yang dapat dipergunakan untuk kepentingan proses/ aktivitas belajar baik secara langsung maupun secara tidak langsung, di luar diri siswa yang melengkapi yang melengkapi diri mereka pada saat pembelejaran berlangsung disebut sebagai sumber belajar.

Fauzi (2015) menjelaskan bahwa mata pelajaran Seni Budaya bertujuan untuk menumbuhkembangkan kepekaan rasa estetik dan artistik, sikap kritis, apresiatif dan kreatif pada diri setiap peserta didik secara menyeluruh. Kegiatan pembelajaran dinyatakan berhasil bila terjadi perubahan tingkah laku pada diri siswa baik itu peningkatan kemampuan, kualitas, kecakapan, pengetahuan, sikap, kebiasaan, pemahaman, keterampilan, daya pikir, dan kemampuan-kemampuan yang lain yang berkaitan dengan mata pelajaran Seni Budaya. Salah satu materi dari mata pelajaran Seni Budaya yang dpelajari untuk tingkat Sekolah Menengah Atas adalah seni rupa dua dimensi. Seni rupa dua dimensi adalah karya seni rupa yang memiliki batas dua sisi, yaitu sisi panjang dan sisi lebar. Seni rupa dua dimensi tidak memiliki ruang karena tidak memiliki ketebalan atau ketinggian. Contoh karya seni rupa dua dimensi dalam kehidupan sehari-hari bisa di lihat pada dekorasi dinding.

Menurut Istarani (2012) penggunaan model role playing dilakukan yaitu: (1) melatih para siswa agar mereka dapat menyelesaikan masalah yang bersifat sosial psikologis; (2) melatih para siswa agar mereka 
dapat bergaul dan memberi pemahaman terhadap orang lain serta masalahnya; (3) menerangkan suatu peristiwa yang didalamnya menyangkut banyak orang. Shoimin (2014) mengemukakan kelebihan model role playing yaitu: melibatkan seluruh siswa berpartisipasi, siswa belajar menggunakan bahasa dengan baik dan benar, siswa bebas mengambil keputusan dan berekspresi secara utuh, permainan merupakan penemuan yang mudah, guru dapat mengevaluasi pengalaman siswa melalui pengamatan ketika bermain peran, berkesan dengan kuat dan tahan lama dalam ingatan siswa, sangat menarik bagi siswa, membangkitkan semangat optimisme dalam diri siswa serta menumbuhkan rasa kebersamaan dan kesetiakawanan, menghayati peristiwa dan memetik hikmah yang terkandung di dalamnya, meningkatkan kemampuan profesional siswa.

Model role playing merupakan kegiatan simulasi yang diarahkan untuk mengkreasikan peristiwa-peristiwa yang berkaitan dengan materi pelajaran. Masingmasing siswa disini akan berperan menjadi beraneka ragam karya seni rupa dua dimensi dan saling berdialog sambil menjelaskan keunikan dirinya mulai dari media, teknik, hingga makna yang terkandung di dalamnya. Dengan demikian, model role playing dianggap efektif dalam mencapai tujuan pembelajaran praktek seperti seni rupa dua dimensi. Hal ini didukung oleh beberapa hasil penelitian terdahulu yang relevan dan telah diterbitkan pada jurnal nasional maupun internasional sebagai berikut: Tetty (2013) membuktikan bahwa terdapat pengaruh signifikan terhadap penggunaan model role playing pada pembelajaran seni rupa dan hasil belajar menggambar siswa. Penelitian Wahyuni (2016) membuktikan bahwa penerapan metode role playing dapat meningkatkan kreativitas siswa, sehingga disarankan guru mata pelajaran Seni Budaya dan Keterampilan menerapkan serta mengembangkan metode role playing di sekolah sebagai upaya untuk meningkatkan kreativitas siswa. Dewi (2017) dalam penelitiannya merekomendasikan model pembelajaran Role Playing untuk diterapkan dalam proses pembelajaran karena model ini dapat meningkatkan pemahaman siswa terhadap materi yang dikaitkan dengan kehidupan nyata. Sejalan dengan penelitian tersebut Sari et al. (2020) menyarankan bagi guru bahwa dalam pelajaran seni rupa khususnya menggambar, tidak hanya menggambar pohon melainkan menggambar lainnya juga guru diharapkan dapat menerapkan prinsip dan unsur seni rupa dengan cara demonstrasi/ praktek langsung sehingga siswa lebih mudah memahami.
Bahwa demikian terbukti bahwa model role playing dapat meningkatkan hasil belajar peserta didik, khususnya pada mata pelajaran Seni Budaya materi seni rupa dua dimensi sebagaimana hasil yang ditemukan dan dianalisis pada penelitian ini.

\section{KESIMPULAN DAN SARAN}

\section{Kesimpulan}

Pada pelaksanaan siklus I, hasil belajar siswa dalam Mata Pelajaran Seni Budaya pada materi Seni rupa dua dimensi memang belum berhasil jika dilihat secara statistik. Namun, ketika pengamatan pada siklus I sudah banyak yang meningkat, mulai dari pemahaman tentang cara mengidentifikasi jenis karya seni rupa dua dimensi dan cara mengidentifikasi unsur-unsur seni rupa dua dimensi. Siswa yang tuntas pada siklus I berjumlah 20 orang dengan presentase $55,56 \%$ dan siswa yang belum mencapai ketuntasan berjumlah 16 orang dengan presentase 44,44\%. Sedangkan pada siklus II, peningkatan hasil belajar secara statistik terlihat dengan jelas. Siswa yang tuntas pada siklus II berjumlah 31 orang dengan presentase $86,11 \%$ dan siswa yang belum mencapai ketuntasan berjumlah 5 orang dengan presentase $13,89 \%$. Berdasarkan hasil penelitian siklus II yang mana terdapat $86,11 \%$ yang tuntas, maka diperoleh kesimpulan bahwa: terjadi peningkatkan hasil belajar siswa menggunakan model role playing pada materi seni rupa dua dimensi di SMAN 1 Labuhan Deli.

\section{Saran}

Diadakannya penelitian tindakan kelas ini, maka guru sebagai peneliti menyarankan bahwa: a). Guru Seni Budaya harus mampu menyesuaikan model pembelajaran dengan materi yang diajarkan, b). Untuk mengajarkan Seni Budaya haruslah dilakukan pemahaman konsep model pembelajaran oleh guru, dan c). Model role playing sangat tepat untuk pembelajaran Seni Budaya pada materi Seni rupa dua dimensi.

\section{DAFTAR RUJUKAN}

A'la, M. (2011). Quantum Teaching. Yogyakarta: Diva Press.

Anderson, H., \& Britton, T. (2000). Stochastics Epidemic Models and their Statistical Analysis. New York: Springer-Verlag.

Angkowo, R., \& Kosasih, A. (2007). Optimalisasi Media Pembelajaran. Jakarta: Grasindo.

Arikunto, Suharsimi. (2010). Prosedur Penelitian Suatu Pendekatan. Jakarta: Rineka Cipta.

Dewi, T. A. (2017). Efektivitas Model Role Playing dalam Meningkatkan Kompetensi Mahasiswa Pada Mata Kuliah Manajemen Keuangan. JURNAL PROMOSI: Jurnal Pendidikan Ekonomi UM Metro, 5(1), 95-104. 
Fauzi, H. D. (2015). Buku Guru Seni Budaya. Bandung: Yrama Widiya.

Istarani. (2012). Model Pembelajaran Inovatif. Medan: Media Persada.

Joyce, \& Weil. (1992). Models of Teaching. USA: Allyn and Bacon.

Tetty Khairiyah, D. (2013). Pengaruh Model Role Playing pada Pembelajaran Seni Rupa Terhadap Hasil Belajar Menggambar Siswa Kelas IV SDN 01 Baso. Serupa The Journal of Art Education, 2(1),

Komaruddin. (2000). Model Pembelajaran Aktif. Bandung: Remaja Rosdakarya.

Mulyasa, E. (2005). Menjadi Guru Profesional. Bandung: Remaja Rosdakarya.

Ngalimun. (2014). Strategi dan Model Pembelajaran. Yogyakarta: Aswaja Pressindo.

Rahmat. (2008). Model Pembelajaran Aktif. Jakarta: Balai Pustaka.

Reigeluth, C. M. . (1983). Instructional Design Theories and Models: An Overview of Their Curent Status. London: Lawren Erlbaum Associates Publisher.

Richey, R. C. (1986). The Theoretical and Conceptual Bases of Instructional Design. London: Kogan Page Ltd.

Rohani, A. (2004). Pengelolaan Pengajaran. Jakarta: Rineka Cipta.

Sagala, S. (2011). Konsep dan Makna Pembelajaran. Bandung: Alfabeta.

Sanjaya, W. H. (2008). Strategi Pembelajaran Berorientasi Standar Proses Pendidikan. Jakarta: Kencana.

Sapriya. (2002). Studi Sosial: Konsep dan Model Pembelajaran. Bandung: Buana Nusantara.

Sari, J., Tarigan, N., Erdansyah, F., \& Sumarsono. (2020). Pengaruh Penguasaan Prinsip Dan Unsur Seni Rupa Terhadap Hasil Belajar Menggambar Flora Di Smp Swasta Al-Ulum Medan. Gorga : Jurnal Seri Rupa, 9(1), 133-137.

Shoimin, A. (2014). 68 Model Pembelajaran Inovatif dalam Kurikulum 2013. Yogyakarta: Ar-Ruzz Media.

Slameto. (2003). Belajar dan Faktor-Faktor yang Mempengaruhinya. Jakarta: Rineka Cipta.

Suprijono, A. (2010). Cooperatif Learning Teori dan Aplikasi. Yogyakarta: Pustaka Belajar.

Uno, H. B. (2003). Model Pembelajaran Menciptakan Proses Belajar Mengajar yang Kreatif dan Efektif. Jakarta: Bumi Aksara.

Uno, H. B. (2009). Perencanaan Pembelajaran. Jakarta: Bumi Aksara.

Wahyuni, S., Mering, A., \& Isti, W. Penerapan Metode Role Playing pada Pembelajaran Seni Tari untuk Meningkatkan Kreativitas Siswa di SMP. Jurnal Pendidikan dan Pembelajaran Khatulistiwa, 5(11), ok, R. M. (2008). Seni Budaya 3. Bogor: Yudhistira Ghalia Indonesia. 